\title{
DOCUMENTAÇÃO E MAPEAMENTO DE DANOS DO OBSERVATÓRIO ASTRONÔMICO DE OLINDA E SUA CORRELAÇÃO COM A CARACTERIZAÇÃO QUÍMICA E MINERALÓGICA DA SUA ESTRUTURA METÁLICA
}

Henry S. Lavalle Sullasi*

Bruno de Oliveira Pinheiro

Júnior**

Anaís Lara Bertrand**

Luísa Danda de Sá**

Maria Luiza Soares Maciel**
RESUMO: Este trabalho teve como objetivo na primeira fase a documentação e levantamento de danos do Observatório Astronômico de Olinda. Na segunda fase foi realizada a caracterização química e mineralógica das estruturas metálicas enferrujadas com o intuito de responder quais são os fatores que ocasionaram, nas duas estruturas de ferro, diferentes graus de corrosão. Para atingir tais objetivos foram realizados análises de FRX e DRX em duas amostras. Os resultados mostraram que se trata de amostras diferentes, com processos de fabricação distintos. Por outro lado a análise visual do tipo de ferrugem, das amostras, indica que os processos de ferrugens observados estão fortemente influenciados pela disposição espacial de cada estrutura metálica na edificação.

Palavras chave: Observatório de Olinda, Mapeamento de danos, FRX, DRX, Ferro.

ABSTRACT: In its first phase, this work was aimed at the documentation and damage assessment of the Olinda Astronomical Observatory. In the second phase, the chemical and mineralogical characterizations of the rusty metal structures were carried out in order to answer which were the factors that caused different degrees of corrosion in the two iron structures. To achieve these objectives, XRF and XRD analyzes were performed in two samples. The results showed that these are different samples, with different manufacturing processes. On the other hand the visual analysis of the rust type of the samples indicates that the observed rust processes are strongly influenced by the spatial arrangement of each metal structure in the building.

Keywords: Damage mapping, Iron, Olinda Observatory, XRD, XRF. 
Documentação e Mapeamento de Danos do Observatório Astronômico de Olinda e sua Correlação com a Caracterização Química e Mineralógica da sua Estrutura Metálica

\section{Introdução}

Em 1860, o francês Emmanuel Liais, a chamado do imperador Dom Pedro II, que era conhecido também por seus interesses astronômicos registrou, nas proximidades a passagem de um cometa, hoje conhecido popularmente como "Olinda", o primeiro cometa descoberto na América Latina (Liais E. 1860) Mais tarde, em 1882, foi notado que o local também teria as condições ideais para observar um raro fenômeno astronômico, o "Trânsito de Vênus", onde o planeta, a Terra e o Sol encontrar-se-iam alinhados (Rizzuti e Silva, 2016).

Diante disso foi construído em 1896, pelo governador Barbosa Lima, o Observatório Astronômico de Olinda, com design Europeu, com intuito de estudar os astros. Serviu de estação meteorológica durante 1920 a 1960 e em 1970 foi desativado (Matsuura, 2010).

Apenas em 2004 foi restaurado e reativado, a partir da administração do Espaço Ciência, visando despertar o interesse científico, divulgando didaticamente a astronomia para a comunidade (Matsuura, 2010). O pouco que há disponível sobre essa restauração foi obtido de forma oral com os funcionários do Espaço Ciência e por análise de fotografias, onde se podem perceber as adições feitas no local. (Figuras 1 e 2 )

O Observatório Astronômico de Olinda está localizado no Alto da Sé, no Sítio Histórico de Olinda. Em uma visita recente a este observatório foi identificada a presença de danos materiais e de ferrugem em grande parte da edificação. A partir das informações obtidas na primeira etapa do estudo do Observatório, foi feito o seguinte questionamento: Quais são os fatores que ocasionaram, nas duas estruturas de ferro, diferentes graus de corrosão?

A hipótese é que há dois principais fatores, uma delas sendo o posicionamento das estruturas na edificação, tendo em vista que uma está protegida em seu interior, enquanto a outra, exposta, recebe uma série de intempéries. O segundo fator seria o período em que foram fabricadas as estruturas. A partir do histórico do edifício, fica evidente que há uma diferença temporal entre os materiais que foram inseridos ali, possibilitando que as grades exteriores tenham sido colocadas na restauração de 2004.

Um estudo químico dos componentes da escada e de uma das janelas fornecerá dados que poderiam ajudar a solucionar os questionamentos. Aliados aos conhecimentos das propriedades químicas, físicas e a forma que se dá a degradação de compostos metálicos e suas patologias, é possível obter um direcionamento. 


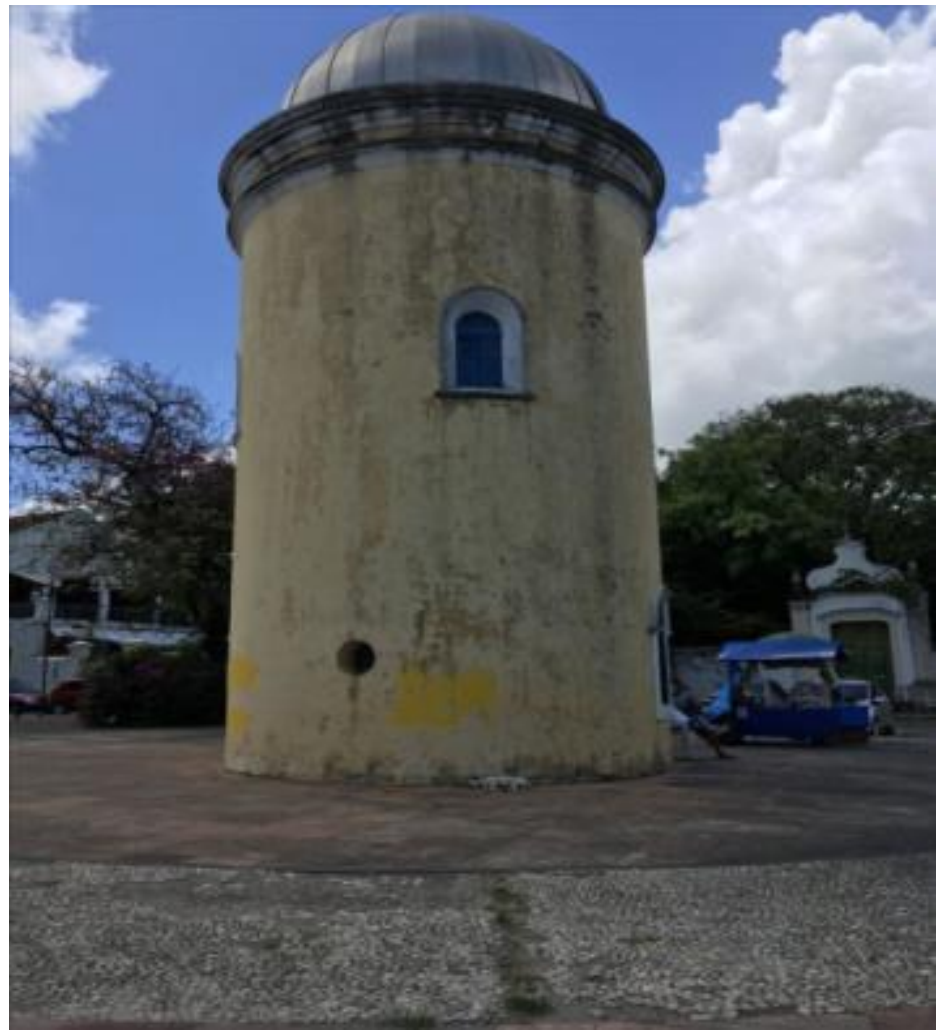

Figura 1 - Observatório após a restauração.. Fonte: Google Imagens, 2017.

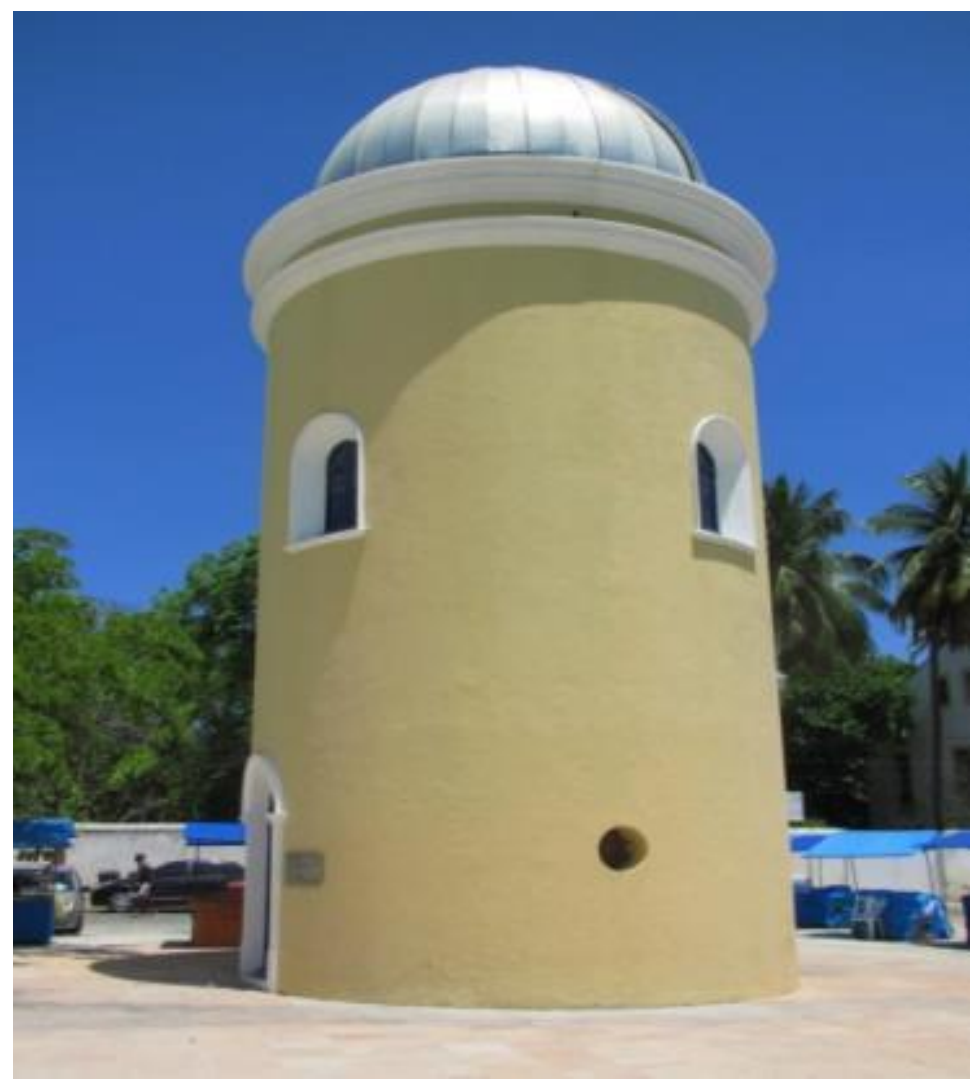

Figura 2 - Observatório Atualmente. Fonte: Google Imagens, 2017. 
Documentação e Mapeamento de Danos do Observatório Astronômico de Olinda e sua Correlação com a Caracterização Química e Mineralógica da sua Estrutura Metálica

\section{Fundamentação Teórica}

Para um melhor entendimento do objeto de estudo, serão aqui abordados as principais propriedades físico-químicas e as patologias em metais, no presente caso o ferro.

Propriedades Físico-Químicas dos Metais

Segundo o cientista Eládio Petrucci (1978), define-se metal como "um elemento químico que existe como cristal ou agregado de cristais no estado sólido, caracterizado pelas seguintes propriedades: alta dureza, grande resistência mecânica, elevada plasticidade, e relativamente alta condutibilidade térmica e elétrica"

Durante o processo de aquecimento e resfriamento, os metais sofrem transformações em sua estrutura. Ao fundir, os átomos se organizam irregularmente. Ao resfriar, solidificam-se, os átomos se arranjam formando estruturas periódicas, chamadas de retículo cristalino (Palache, 1935).

Segundo Petrucci (1978), existe quatorze tipos possíveis estruturas cristalinas que os átomos tendem a formar quando o metal solidifica, entre eles os sistemas cristalinos: cúbico, tetragonal, hexagonal, romboédrico, ortorrômbico, monoclínico e triclínico. Entretanto, a maioria dos metais cristaliza de acordo com três tipos de reticulado: cúbico centrado, cúbico de face centrada e hexagonal.

\section{Produtos Siderúrgicos}

A mistura de metais com um ou mais corpos simples, que podem ser metais ou metaloides, geram as chamadas ligas metálicas ou ligas metálicas especiais, que apresentam propriedades distintas. Existem os minérios, que são combinações com outros elementos formando óxidos, sulfetos, hidratos, carbonatos etc., e a junção deles com a liga metálica formam os produtos siderúrgicos. Dentre esses produtos, os aços (com até $2 \%$ de carbono) e os ferros fundidos (com mais de $2 \%$ de carbono) são os mais importantes.

$\underline{O a c ̧ o}$

Como visto em Petrucci (1978), denomina-se aço todo produto siderúrgico obtido por via líquida e com teor de carbono inferior a $2 \%$. Usualmente, classifica-se o aço pelo seu teor de carbono, da seguinte maneira:

- Aços extra doces $(<0,15 \% \mathrm{C})$;

- Aços doces $(0,15$ a $0,3 \% \mathrm{C})$;

- Aços meio-doces (0,3 a 0,4\% C); 
- Aços meio-duros $(0,4$ a $0,6 \% \mathrm{C})$;

- Aços duros (0,6 a 0,7\% C);

- Aços extra duros $(>0,7 \% \mathrm{C})$

Conforme Petrucci (1978), quanto maior for a granulação, mais frágil será o material e menos propriedades mecânicas apresentará.Esse processo, porém, pode ser reparado com o encruamento, que consiste em alterar as propriedades do materialaquecendo-o por normalização ou têmpera, recozimento, revenido ou por tratamentos isotérmicos. Onde a primeira aquecerá o material acima da temperatura crítica, em seguida esfriando-o ao ar livre para assim atingir uma estrutura homogênea; a segunda também aquecerá o material acima da temperatura crítica, mas o resfriamento será de forma imediata. No recozimento o aquecimento pode ser feito com temperaturas acima ou abaixo da temperatura crítica, porém seu esfriamento será de forma lenta.Em contrapartida, a revenido aquece o material sempre abaixo da temperatura crítica e esfria ao ar, água ou óleo. Por fim, nos tratamentos isotérmicos se utiliza temperaturas superiores e esfria-se a uma temperatura específica.

\section{Ferro Fundido}

Produto siderúrgico que apresentam mais de $2 \%$ de carbono, quanto mais carbono em sua estrutura, mais duro se torna, ao ponto de não conseguir forjar, estirar, laminar ou vergar o material. Sua temperatura de fusão baixa o torna um produto mais barato e acessível.

Os ferros fundidos eram empregados apenas em peças destinadas a sofrerem pequenos esforços, exceto os de compressão. Isso porque os produtos obtidos eram frágeis. Graças ao aperfeiçoamento dos processos, obtêm-se hoje ferros fundidos mais maleáveis.

Ainda de acordo com Petrucci (1978), o ferro fundido apresenta carbono em duas formas possíveis: cementita ou grafite. A partir daí, é possível separá-lo em dois grupos: brancos e cinzentos. Quando todo o carbono se apresenta sob a forma de Cementita $\left(\mathrm{Fe}_{3} \mathrm{C}\right)$, a fratura da peça é clara, dando o nome de ferro fundido branco; quando o carbono apresenta-se sob a forma de grafite, a fratura é escura, e o ferro fundido é chamado de cinzento.

Outro fator determinante para a obtenção de ferro fundido branco ou cinzento é a velocidade de esfriamento. Através da velocidade desse processo, atenua-se ou evita-se a formação de grafite, conseguindo-se obter ferros fundidos brancos com composições que normalmente seriam de ferros fundidos cinzentos (Petrucci, 1978).

O ferro fundido cinza é menos duro e frágil que o branco, podendo facilmente ser trabalhado em oficina. O emprego do ferro fundido branco é restrito aos casos onde se necessita de dureza e de elevada resistência ao desgaste.

Quando a composição química e a temperatura de resfriamento são contraditórias, pode-se obter um terceiro tipo, o ferro fundido coquilhado. Esse material apresenta em sua superfície, onde se deseja dureza e resistência ao desgaste, o ferro fundido branco. E no interior, material menos frágil, o ferro fundido cinza (Giardino, 1998). 
Documentação e Mapeamento de Danos do Observatório Astronômico de Olinda e sua Correlação com a Caracterização Química e Mineralógica da sua Estrutura Metálica

\section{Metais Não Ferrosos}

O emprego de metais não ferrosos se limita a casos em que se faz necessário o aproveitamento de alguma de suas propriedades características, como: resistência à corrosão; pequenas densidades; propriedades elétricas e magnéticas; características especiais de resistência e ductilidade, além da fusibilidade.

Propriedades Mecânicas dos Metais

Conforme Giardino (1998), uma característica evidente e imediata dos metais é que são opacos e refletem a luz, o que os confere o típico brilho metálico. São também, sólidos à temperatura ambiente e quando submetidos ao calor, se dilatam. Esta propriedade costuma ser expressa através do coeficiente médio de dilatação térmica linear.

Petrucci (1978) agrupa as características físicas dos metais em três categorias: Constantes físicas; Propriedades Elétricas e Magnéticas; e por fim, Características Mecânicas.

Giardino (1998) afirma que os metais se distinguem por reagirem de maneira própria aos esforços mecânicos. De todos os materiais, nenhum se assemelha em dureza ou tenacidade. Esta foi, provavelmente, uma das principais características que levaram o homem pré-histórico a utilizá-los para armas e utensílios. Geralmente, os mais duros são aqueles com ponto de fusão mais elevado.

Outra característica importante é a maleabilidade. Os metais podem ser transformados em lâminas, exercendo compressão sobre eles, por exemplo, martelando-os. Além de serem flexíveis, podendo esticar-se ou comprimir-se sem romper ou quebrar (Giardino, 1998).

Quando o metal é submetido acerta tensão de carga, ele se deforma elasticamente, recuperando sua forma e dimensões iniciais uma vez que o estresse tenha cessado. Se, no entanto, o estresse a que foi submetido for suficientemente intenso, a deformação produzida será permanente, denominada deformação plástica (Giardino, 1998).

\section{Principais Patologias em Metais}

O termo patologia deriva do grego "pathos", que pode ser entendido como doença ou sofrimento, e "Logus", estudo, portanto, pode ser entendida como a ciência que estuda as doenças (Santos 2018). Na medicina, estuda tanto as alterações estruturais e funcionais das células, quanto dos tecidos e órgãos relacionados às doenças. Na engenharia, utiliza-se do termo ao observar a construção como um organismo em interação com o meio. Podendo, portanto, ter uma relação saudável ou patológica, e sofrendo com suas consequências.

Cada edificação possui características construtivas, decorrente dos métodos utilizados em sua formulação, que o farão reagirem de formas diferentes aos impactos externos e internos capazes de gerar danos estruturais. A maioria das patologias pode ser evitada a partir de preparo inicial e planejamento, além de manutenções (Cozza 1998). 
Segundo Cozza (1998), é possível separar as principais patologias das estruturas metálicas em três grupos:

\section{- $\quad$ Adquiridas}

Decorrente de elementos externos, conhecidos como agentes agressivos, como líquidos corrosivos, atmosfera poluída, incêndios, vibrações, entre outros. Relacionado com a ausência de manutenção e/ou pouca preparação preliminar da estrutura, se tornando incapaz de se adaptar às ações de tais agentes. O produto mais visível e frequente é a corrosão.

\section{- $\quad$ Transmitidas}

Originada de desconhecimento técnico na construção, fabricação ou montagem da estrutura. O uso de soldas em superfícies pintadas, enferrujadas, áreas sujeitas a infiltração, ou ainda a ausência de prumo são alguns exemplos de danos gerados por tal patologia.

\section{- $\quad$ Atávicas}

Gerado por má efetivação do projeto, relacionado com o descuido, como erros de cálculos, escolha de espessuras erradas, assim como de materiais com ligas menos resistentes que as planejadas e estabelecidas. São as mais difíceis de serem reparadas e a mais desvantajosa, de acordo com os custos que vão gerar.

As estruturas metálicas são mais comumente atacadas pela oxidação, e a partir daí, sofrem corrosão. Um processo comum aos metais que faz com que eles percam suas qualidades essenciais, como resistência mecânica, elasticidade, ductilidade e estética.

O tipo mais comum de corrosão é através da oxidação eletroquímica do metal, ocorrendo a perda de elétrons e dando origem a outras reações com formação de ferrugem (Hidróxido de Ferro), 4Fe(OH) ${ }_{3}$ ) (GIARDINO, 1998). Segundo Petrucci (1978), para que se dê a corrosão devemos ter, além da perda de elétrons, a existência de oxigênio e umidade. Os metais possuem diferentes quantidades de energia necessária para a remoção de elétrons, por isso possuem diferentes potenciais de oxidação. Esse processo, lento em meio alcalino ou neutro, é facilitado em meio ácido.

Segundo Araújo (2012), a corrosão pode ser classificada quanto à sua morfologia dentro dos seguintes tipos: uniforme, pitting, intergranular, transgranular, filiforme, empolamento pelo hidrogênio e em torno do cordão de solda (Figura 3).

- Corrosão Generalizada: se processa em toda a extensão da superfície, ocorrendo perda uniforme de espessura. Também é conhecida como corrosão generalizada.

- Corrosão por Pitting: engloba três classificações de corrosão.

- $\quad$ Por placas: corrosão que se localiza em regiões da superfície metálica e não em toda extensão, formando placas com escavações.

- Alveolar: corrosão que se processa na superfície metálica produzindo sulcos ou escavações semelhantes a alvéolos, apresentando fundo arredondado e profundidade geralmente menor que seu diâmetro. 
Documentação e Mapeamento de Danos do Observatório Astronômico de Olinda e sua Correlação com a Caracterização Química e Mineralógica da sua Estrutura Metálica

- Puntiforme: corrosão que ocorre em pontos ou pequenas áreas localizadas na superfície metálica produzindo pites, que são cavidades que apresentam o fundo em forma angulosa e profundida geralmente maior que o seu diâmetro.

- Corrosão Intergranular ou Intercristalina: localiza-se entre os grãos da estrutura cristalina do material metálico, o qual perde suas propriedades mecânicas e pode fraturar quando submetido a esforços mecânicos menores que o esperado, como é o caso da corrosão sobtensão fraturante.

- Corrosão Transgranular, Transcristalina ou Intragranular: acontece nos grãos cristalinos da rede cristalina do material metálico, o qual, pela perda de suas propriedades mecânicas, poderá fraturar ao menor esforço mecânico, assim como no caso da corrosão intragranular. Entretanto, seus efeitos são muito mais catastróficos que os da corrosão intergranular.

- Corrosão Filiforme: se processa sob a forma de finos filamentos, mas não profundos, que se propagam em diferentes direções, mas não se cruzam. Ocorre geralmente em superfícies metálicas revestidas com filmes poliméricos, tintas ou metais, ocasionando o deslocamento do revestimento. Dá-se com maior frequência em ambientes cuja umidade relativa do ar é maior que $85 \%$, em revestimentos mais permeáveis à penetração de oxigênio e água ou em materiais apresentando defeitos, como riscos.

- Corrosão por Empolamento pelo Hidrogênio: no estado atômico, o hidrogênio tem grande capacidade de difusão em materiais metálicos. Dessa forma, se o hidrogênio for gerado na superfície de um material, ele migra para o interior e acumula-se em defeitos existentes, como laminações ou inclusões não metálicas. Esse hidrogênio pode ser resultante da decomposição da água de cristalização, contida em alguns tipos de revestimento de eletrodo, em processos de soldagem. Mas também pode ser produto de alguns tipos de reações de corrosão, ou ainda ser gerado pela ação de gases ricos em hidrogênio, ou por meio de outros processos. O hidrogênio acumulado passa da forma atômica à molecular, provocando altas pressões no interior da falha. Quando o acúmulo de hidrogênio ocorre em falhas próximas à superfície, a deformação pode provocar empolamentos, sendo comum denominar esse processo de empolamento pelo hidrogênio.

- Corrosão em Torno do Cordão de Solda: tipo que se observa na zona termicamente afetada durante pelo processo de soldagem.

\section{A Formação da Ferrugem}

Como pode ser visto em Sartorti (2008), para que os metais encontrados na natureza possam ser utilizados com adequada resistência e funcionalidade, necessitam passar por um processo chamado de redução química, onde os óxidos são retirados, resultando no metal puro. 0 processo inverso à redução química é a oxidação, onde o metal tende a associar-se novamente com os óxidos, voltando ao estado natural.

A causa mais frequente de deterioração de estruturas metálicas é a oxidação. A corrosão é um efeito eletroquímico, onde existe uma reação química associada a um potencial elétrico. Para que a corrosão aconteça, é necessária a presença de um eletrólito (água), oxigênio e uma diferença de potencial elétrico. Este diferencial é criado quando átomos de ferro deixam a estrutura para se diluírem na água, deixando a barra com uma carga negativa e a solução aquosa com carga positiva gerada pelos íons de $\mathrm{Fe}^{++}$. 

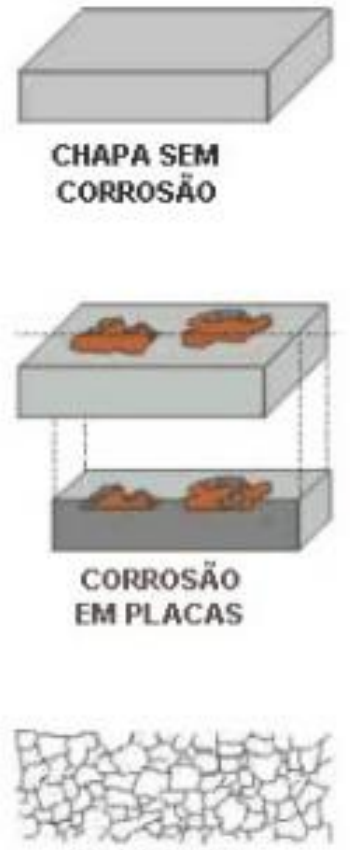

CORROSÄO IMTERGRANULAR (MICROGRAFIA)

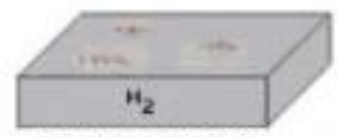

EMPOLAMENTO PELO HIDROGÊHIO
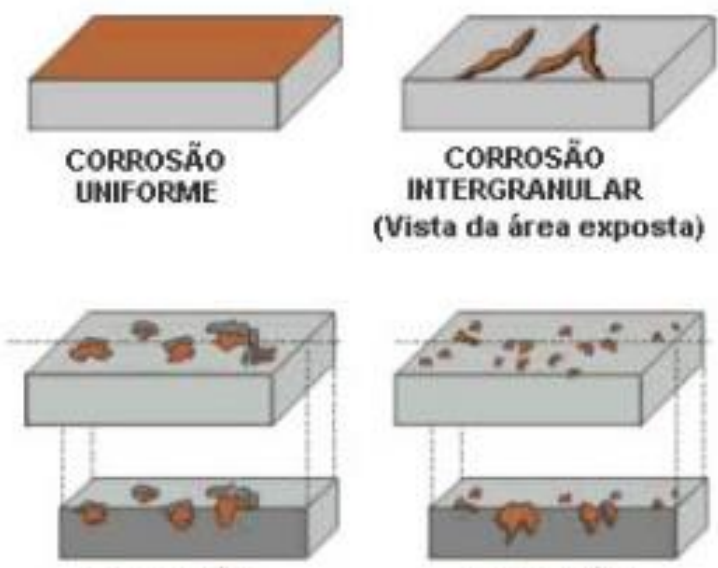

CORROSÄO

ALVEOLAR

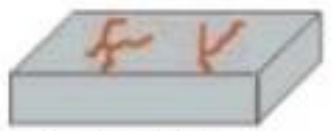

CORROSÃO

FILIFORME

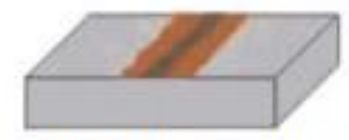

CORROSAOO EM TORNO DA SOLDA
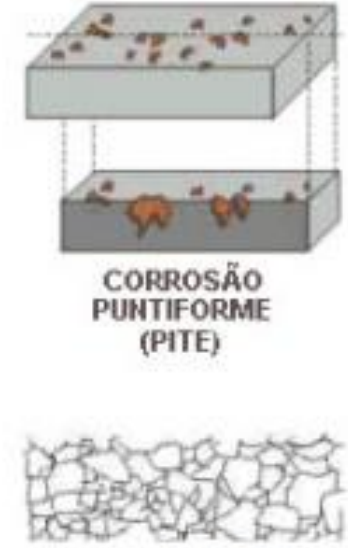

CORROSÃO

INTRAGRANULAR

(MICROGRAFIA)

Figura 3 - Classificação das corrosões segundo sua morfologia. Fonte: Araújo, 2012.

O fenômeno da pilha eletroquímica, segundo Castro (1999), é o processo que explica como se dá a oxidação. A corrosão eletroquímica ocorre através do deslocamento de elétrons entre o ânodo e o cátodo. $O$ ânodo é o elemento ou região que possui maior potencial elétrico, em que a corrente elétrica sai do material e onde ocorre o desgaste por corrosão. $\mathrm{O}$ cátodo é o elemento ou região onde ocorrem as reações. É o responsável pela origem do fenômeno de corrosão e não sofre o desgaste da corrosão. Ainda é importante definir-se eletrólito, como a solução condutora que envolve as regiões anódica e catódica.

$\mathrm{Na}$ estrutura metálica com carga negativa (ânion), o ferro perde elétrons, ocasionando a dissolução do metal através da reação de oxidação à seguir:

$$
2 \mathrm{Fe} \rightarrow 2 \mathrm{Fe}^{2+}+4 \text { é } \quad \text { (oxidação) }
$$

Nas zonas catódicas, a água, em contato com o oxigênio e os elétrons perdidos pelo ferro na reação de oxidação dão origem a 4 moléculas de hidroxila, ocorrendo:

$$
2 \mathrm{H}_{2} \mathrm{O}+\mathrm{O}_{2}+4 \mathrm{e} \rightarrow 4 \mathrm{OH}^{-} \quad \text { (redução) }
$$


Documentação e Mapeamento de Danos do Observatório Astronômico de Olinda e sua Correlação com a Caracterização Química e Mineralógica da sua Estrutura Metálica

A formação da ferrugem ocorre da reação entre o ferro, o oxigênio e a água, dando origem ao Hidróxido de Ferro, uma das formas em que o ferro é encontrado na natureza, de acordo com a seguinte reação:

$$
4 \mathrm{Fe}+3 \mathrm{O}_{2}+6 \mathrm{H}_{2} \mathrm{O} \rightarrow 4 \mathrm{Fe}(\mathrm{OH})_{3} \quad \text { (ferrugem) }
$$

Conforme Petrucci (1978), a acidez do meio (pH inferior a 3) indica que deve haver grandes aumentos na atividade de corrosão. É também importante salientar que, a existência de sais dissolvidos na superfície serve como catalizador da corrosão, por causa da condutividade eletrolítica da solução e porque os produtos da reação tendem a combinar-se na superfície do ferro e precipitar uma camada protetora menor.

Outro fator importante para a velocidade da corrosão é a composição química do material. 0 teor de carbonato não é importante na determinação da velocidade de corrosão. No entanto, quando há a ação de ácidos, a corrosão cresce com o teor de carbono.

Petrucci (1978) afirma que o Manganês (Mn), o Enxofre (S), o Silício (Si) e o Fósforo (P) geralmente aparecem em pequenas porcentagens na composição dos objetos metálicos, sendo insignificantes para o processo de corrosão quando em interação com água pura ou alcalina. Nas águas ácidas, a presença de manganês, enxofre e fósforo tendem a aumentar a corrosão. O silício não tem nenhum efeito, a não ser em elevados teores, tornando o material ácido-resistente.

\section{Materias e Métodos}

\section{O Objeto de Estudo}

O observatório astronômico de Olinda está localizado no Alto da Sé, no Sítio Histórico de Olinda (Figura 4) e possui três pavimentos, feitos inteiramente de alvenaria, onde a mudança mais notável foi a adição da cúpula de ferro adotada para melhor funcionalidade do local. A edificação possui uma única entrada, tendo três janelas no térreo e quatro em seu primeiro andar. No terceiro piso, a observação externa é feita através da cúpula. Em seu interior, há apenas uma escada helicoidal situada a esquerda da porta.

\section{Levantamento Arquitetônico e Mapeamento de Danos}

A elaboração das plantas arquitetônicas foi efetuada a partir das medições feitas da edificação interna e externa e com ajuda do software AutoCad. Paralelamente foi realizado um registro fotográfico minucioso que serviu para o levantamento de danos da edificação.

\section{Coletadas das Amostras}

As coletas foram realizadas com a utilização de luvas de proteção, todas ferramentas e objetos utilizados nos procedimentos de coleta e armazenamento foram de materiais plásticos, para 
evitar também contaminação, que poderia ocorrer com o uso de outro material também metálico. As amostras foram etiquetadas por ordem de coleta, sendo então OAS1 a janela externa, OAS2 a cúpula e OAS3 a escada. Todo o processo foi registrado por meio de fotografias, que mostram os cuidados tomados e o estado em que estavam pontos escolhidos para retirada da amostra no dia da coleta (Figura 5).

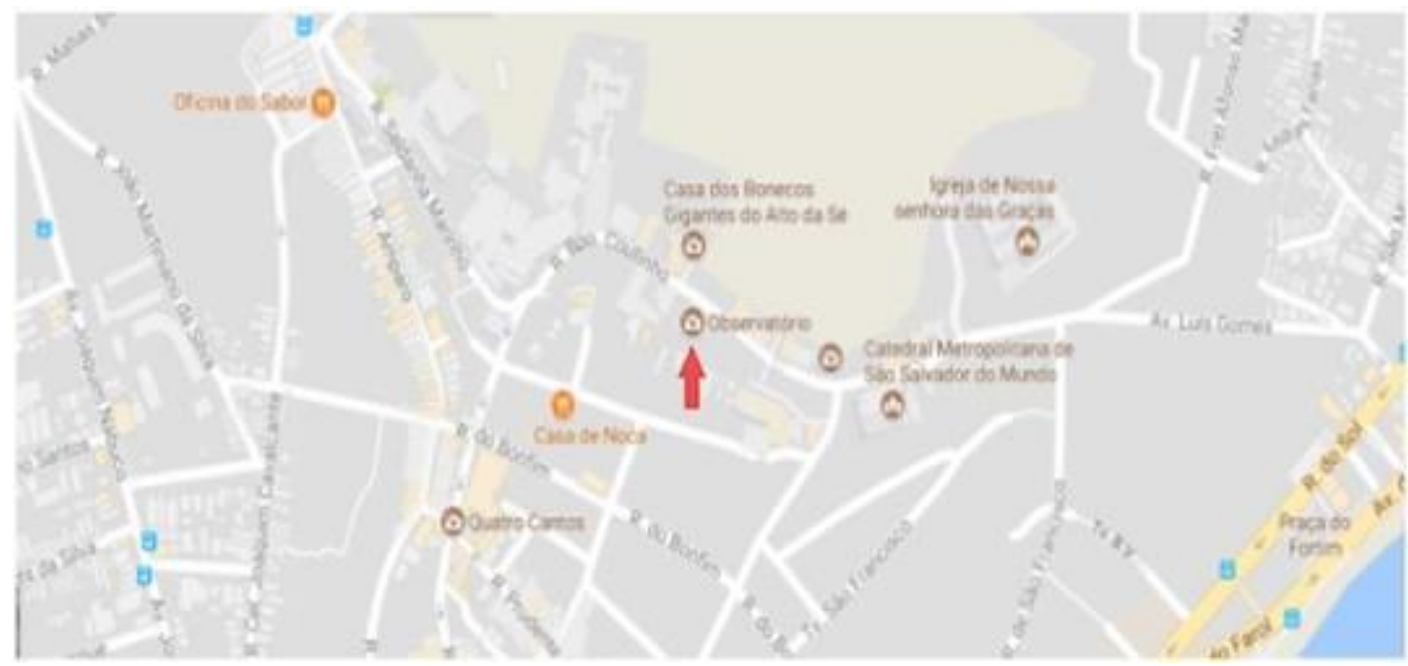

Figura 4 - Mapa da região do Observatório. Fonte: Google Maps, 2017.

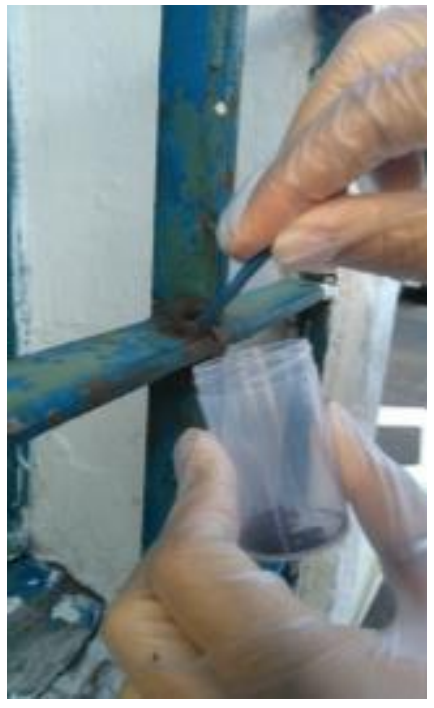

A.

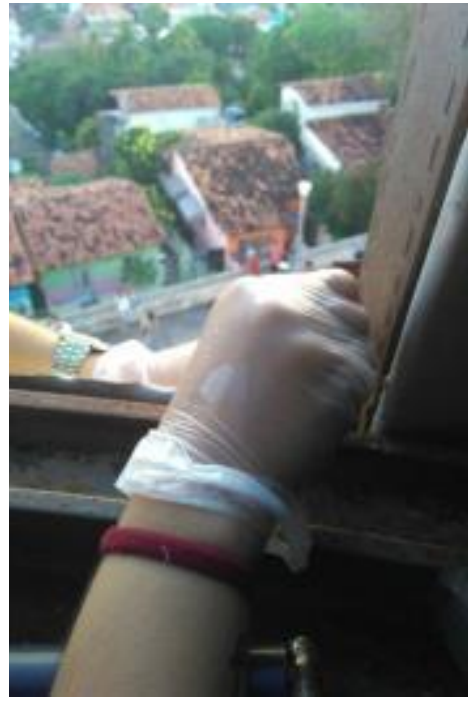

B.

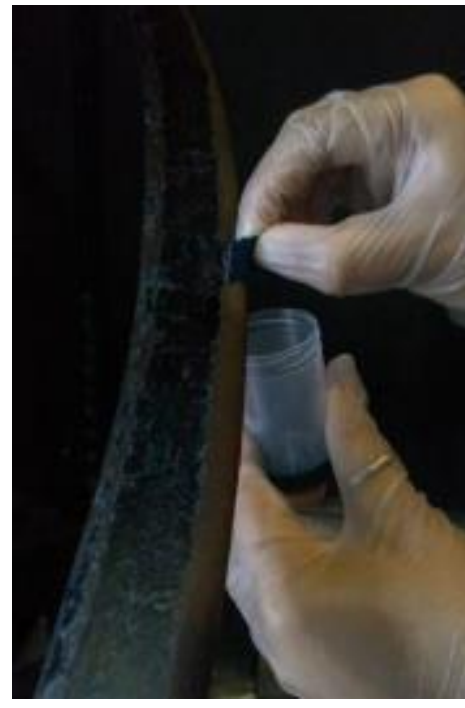

C

Figura 5 - A. Coleta OAS1 na Janela Externa; B. Coleta OAS2 na Cúpula; C. Coleta OAS3 na Escada. Fonte: Acervo Pessoal.

Caracterização por Fluorescência de Raios X e Difração de Raios X

As amostras foram preparadas no Laboratório de Metrologia da Universidade Federal de Pernambuco, através de uma seleção manual e trituração mecânica com auxílio de pilão de 
Documentação e Mapeamento de Danos do Observatório Astronômico de Olinda e sua Correlação com a Caracterização Química e Mineralógica da sua Estrutura Metálica

cerâmica (Figuras 6). A coleta da amostra OAS2 (cúpula) não obteve material suficiente para análises, por tanto não foi utilizada na sequência dos estudos.
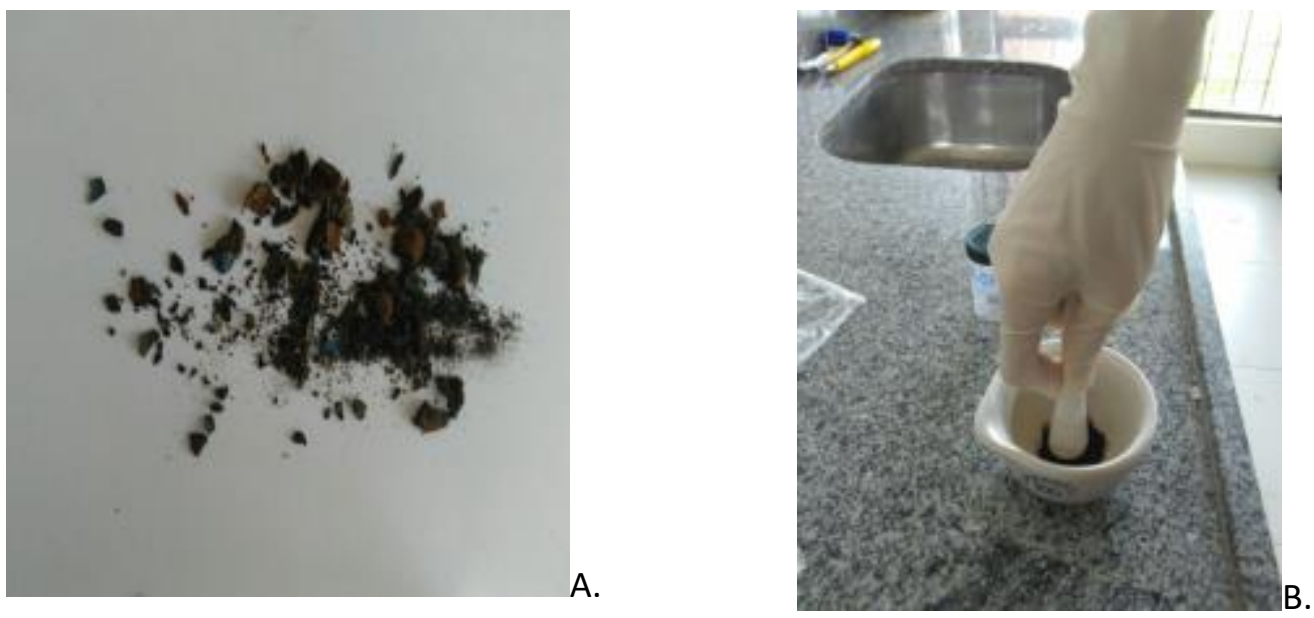

Figura 6 - A.Seleção manual de amostra; B. Processo de trituração para preparo de amostra. Fonte: Acervo Pessoal.

Duas técnicas, a Fluorescência de Raios X (FRX) e Difração de Raios X (DFRX) (Bleicher e Sasaki, 2000) (Calza, 2010), foram utilizadas, buscando associar, as patologias no material coletado a sua composição química e mineralógica das amostras.

Os espectros de FRX da amostra do elemento metálico coletado foram obtidos em laboratório através de um espectrômetro FRX portátil modelo X-MET. Com ele foram realizadas três medidas de uma mesma amostra, com o tempo de acumulação de 30 segundos.

Os difratogramas foram obtidos usando um equipamento de difração de raios- $X$ modeloMiniflex 600 da Rigaku. $O$ processo de indexação das fases cristalinas foi feito com a ajuda do software Match!. O tratamento e a apresentação dos gráficos foi realizado usando o software OriginLab.

\section{Resultados e Discussões}

Levantamento Arquitetônico

A partir das medidas de todas as dimensões da edificação foram confeccionadas as plantas, mostradas nas Figuras 7, 8, 9 e 10. As plantas foram utilizadas para entender a distribuição espacial da estrutura metálica, assim como, para o registro dos pontos de coleta das amostras analisadas pela FRX e DRX. 

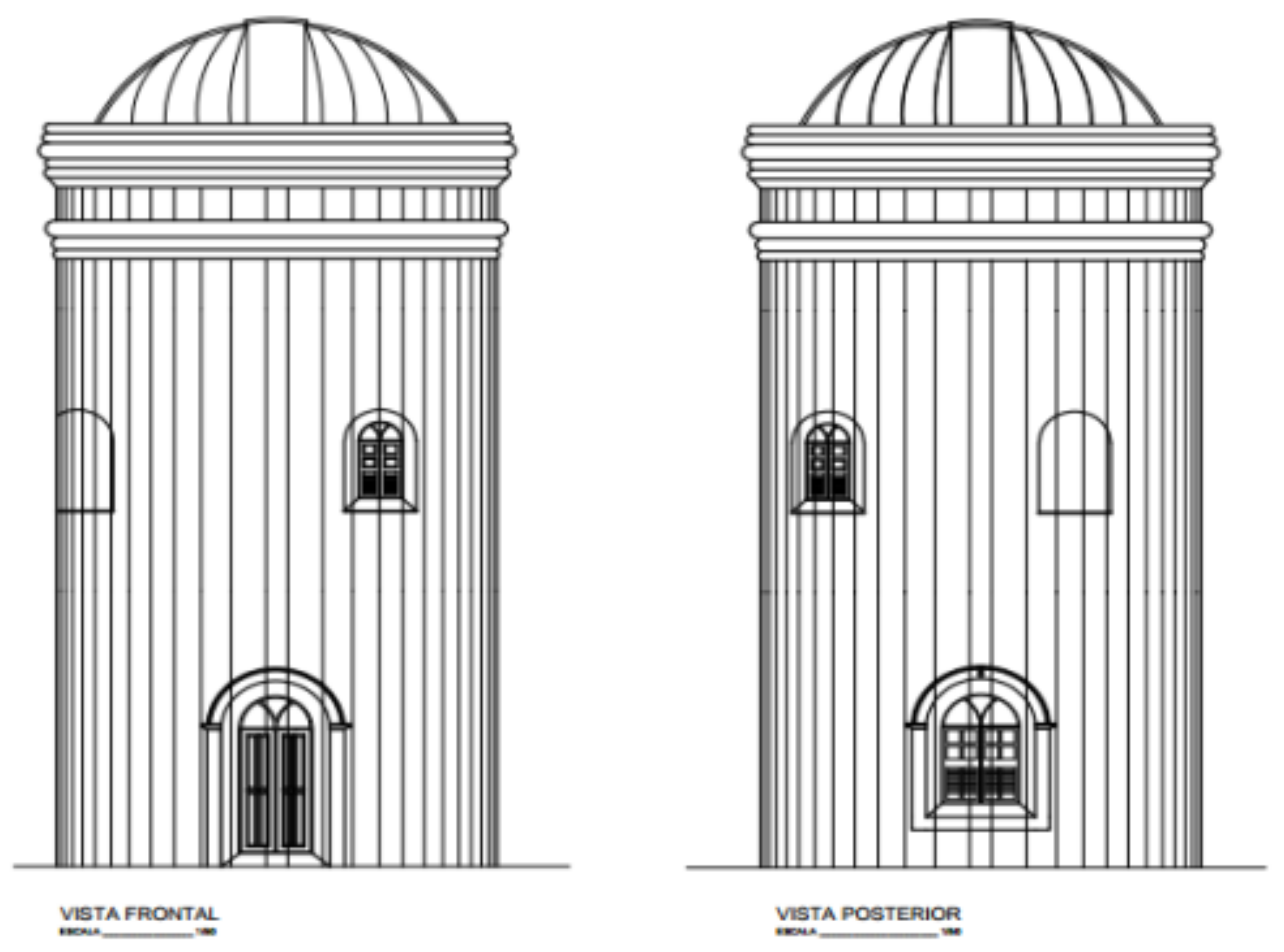

Figura 7 - Vistas Frontal e Posterior do Observatório. Imagem fora de escala.
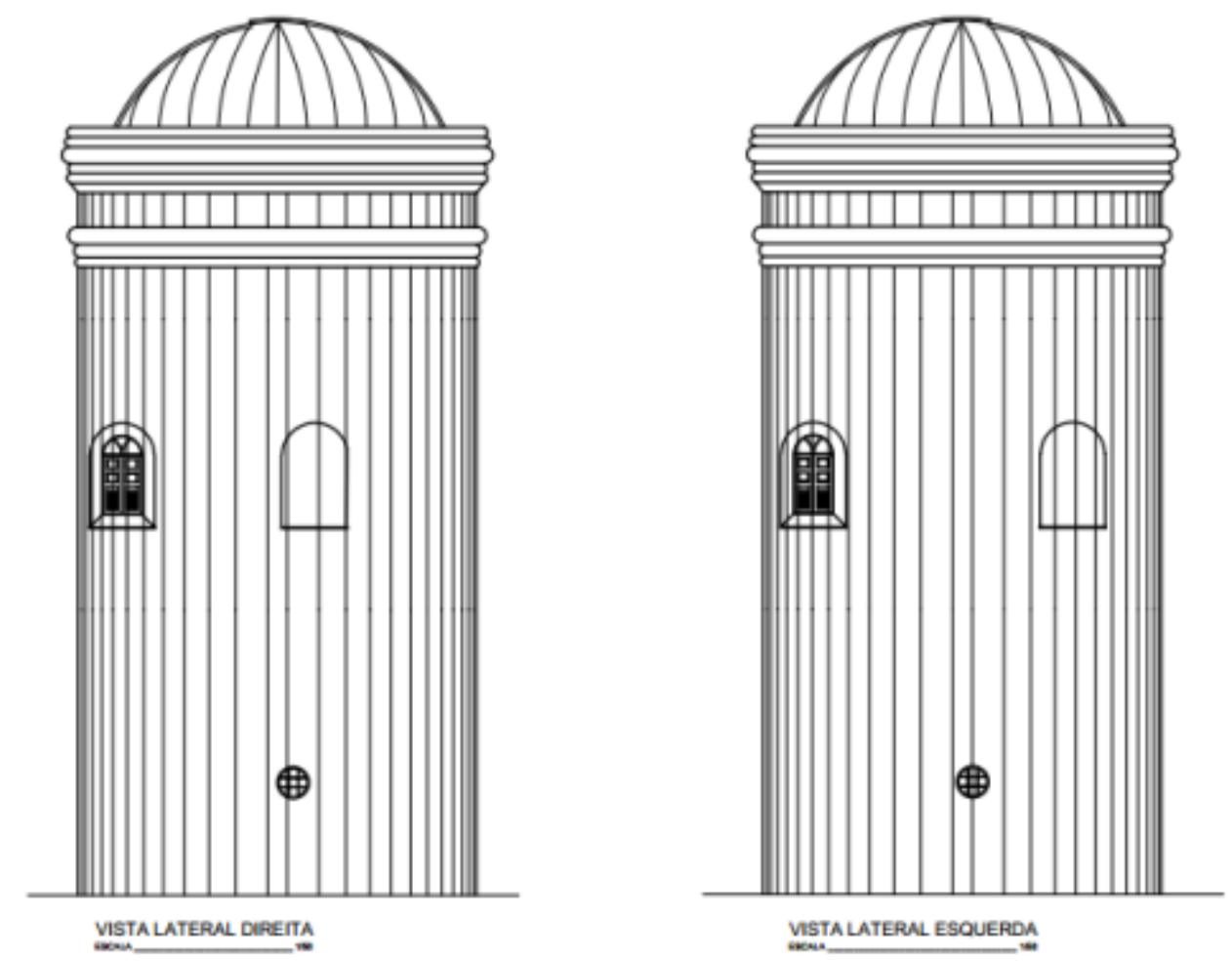

Figura 8- Vistas Laterais do Observatório. Imagem fora de Escala. 
Documentação e Mapeamento de Danos do Observatório Astronômico de Olinda e sua Correlação com a Caracterização Química e Mineralógica da sua Estrutura Metálica
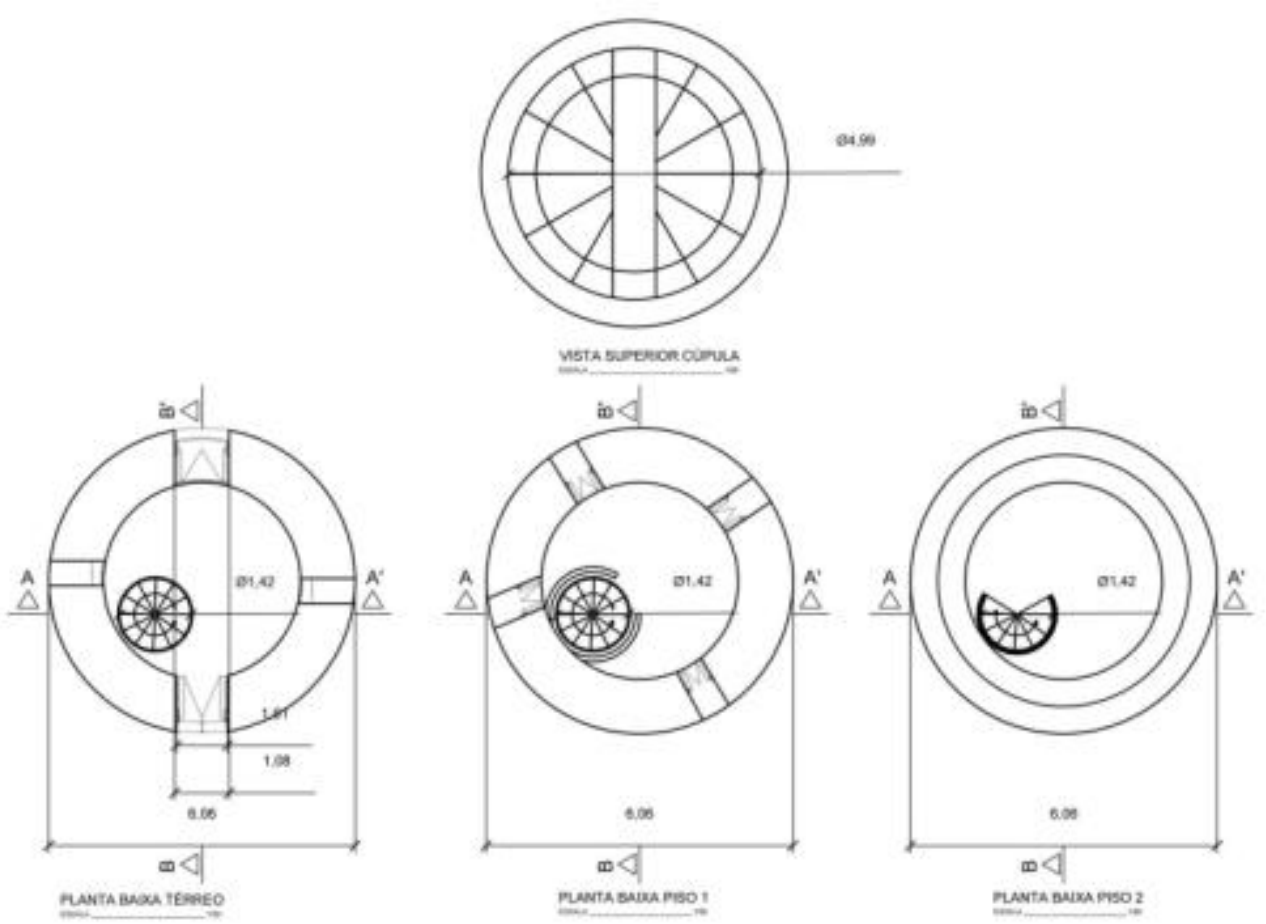

Figura 9 - Plantas dos pisos e Vista Superior da cúpula. Imagens fora de escala.

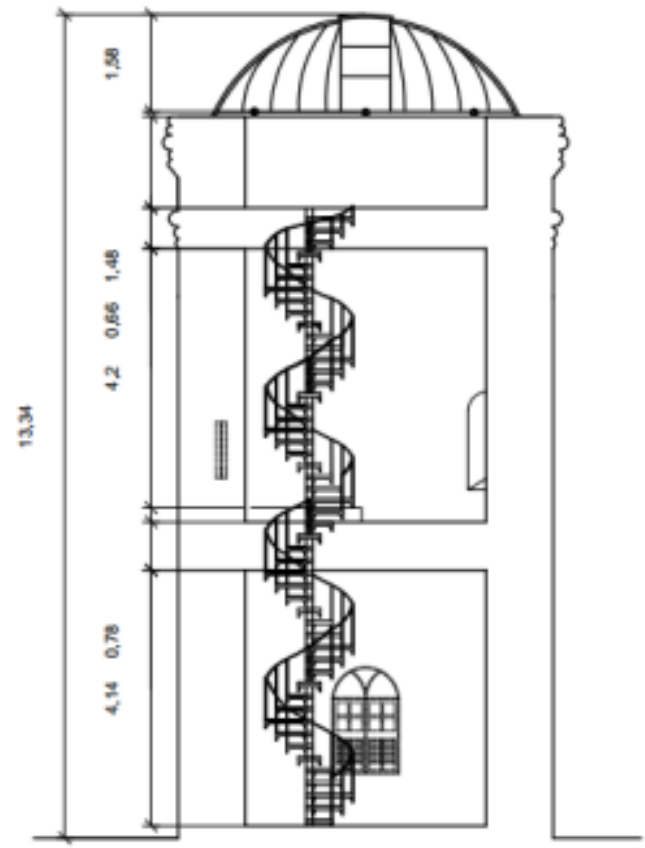

CORTEAR

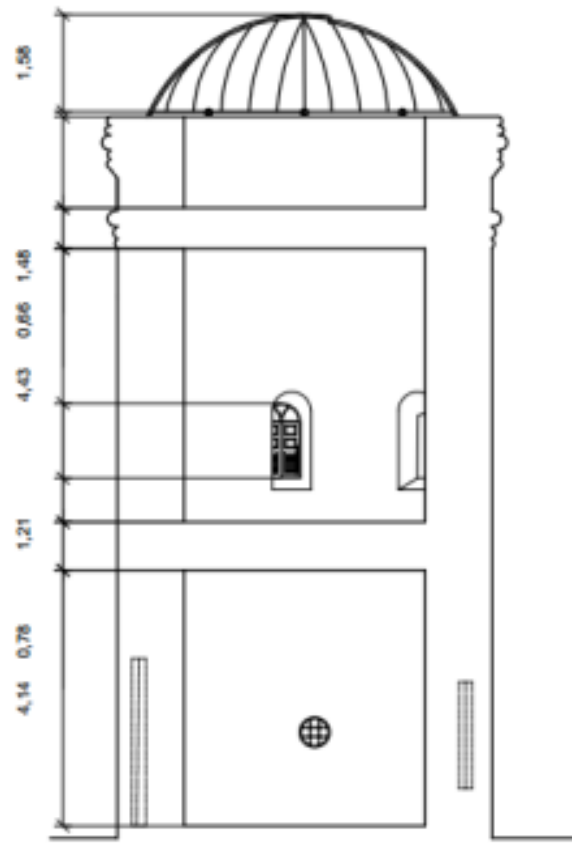

CORTE B E

Figura 10 - Cortes do Edifício. Imagem fora de escala. 
Mapeamento de Danos

A partir da análise das fotografias e com base nas recomendações de Lucena (2009) e Tirello e Corrêa (2010) foi elaborada uma tabela, que deu origem a um gráfico reunindo todos os danos (figura 14) , demonstrando a oxidação do material metálico como o dano mais recorrente, representa o $33 \%$ de todos os danos (Figura 11).

Figura 11 - Gráfico de danos no Observatório Astronômico de Olinda.

\section{MAPA DE DANOS}
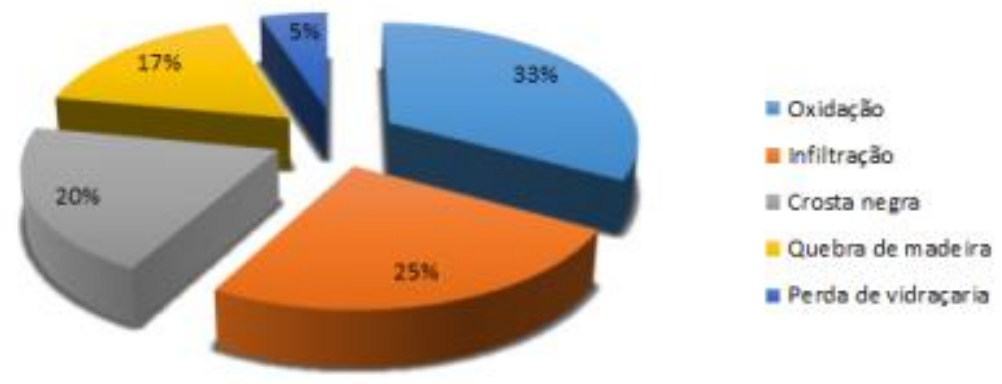

Nenhuma estrutura metálica presente no Observatório Astronômico de Olinda ficou imune à oxidação (ferrugem). A cúpula, apesar de, provavelmente, ter sido a estrutura mais recente também se encontra danificada onde estão as roldanas (Figura 12), apresentando pontos mais localizados de ferrugem.

É possível observar a presença de oxidação generalizada branda na escada (Figura 13), perceptível apesar das camadas de tinta aplicadas em sua superfície de forma paliativa. Apesar de parecer ser mais antiga, não apresentam tantos danos como as demais estruturas.

As grades externas, presentes nas três janelas do térreo, apresentam desgastes, mas a maior, localizada na parte posterior (Figura 14) é a mais degradada, por não ter proteção alguma (uma vez que as janelas laterais se encontram dentro do prédio). A ferrugem espalhou-se por quase toda superfície, gerando descamação uniforme, além de formação de bolhas observadas nas interseções da grade. 
Documentação e Mapeamento de Danos do Observatório Astronômico de Olinda e sua Correlação com a Caracterização Química e Mineralógica da sua Estrutura Metálica
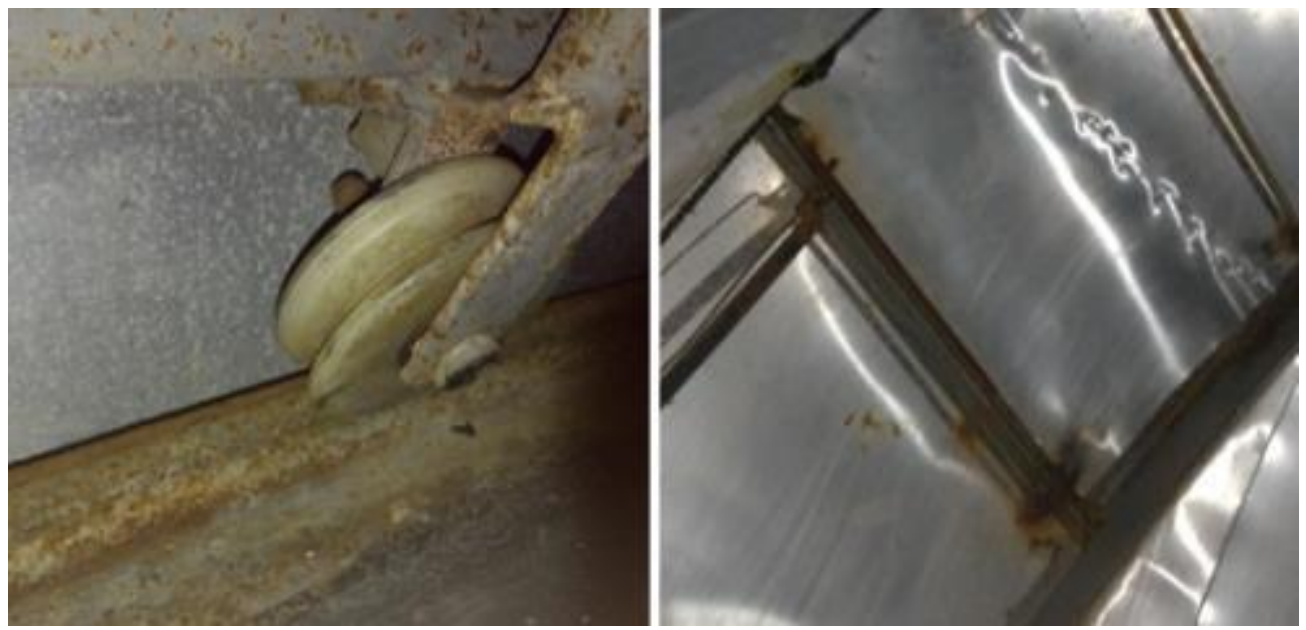

Figura 12 - Estado do material na cúpula.

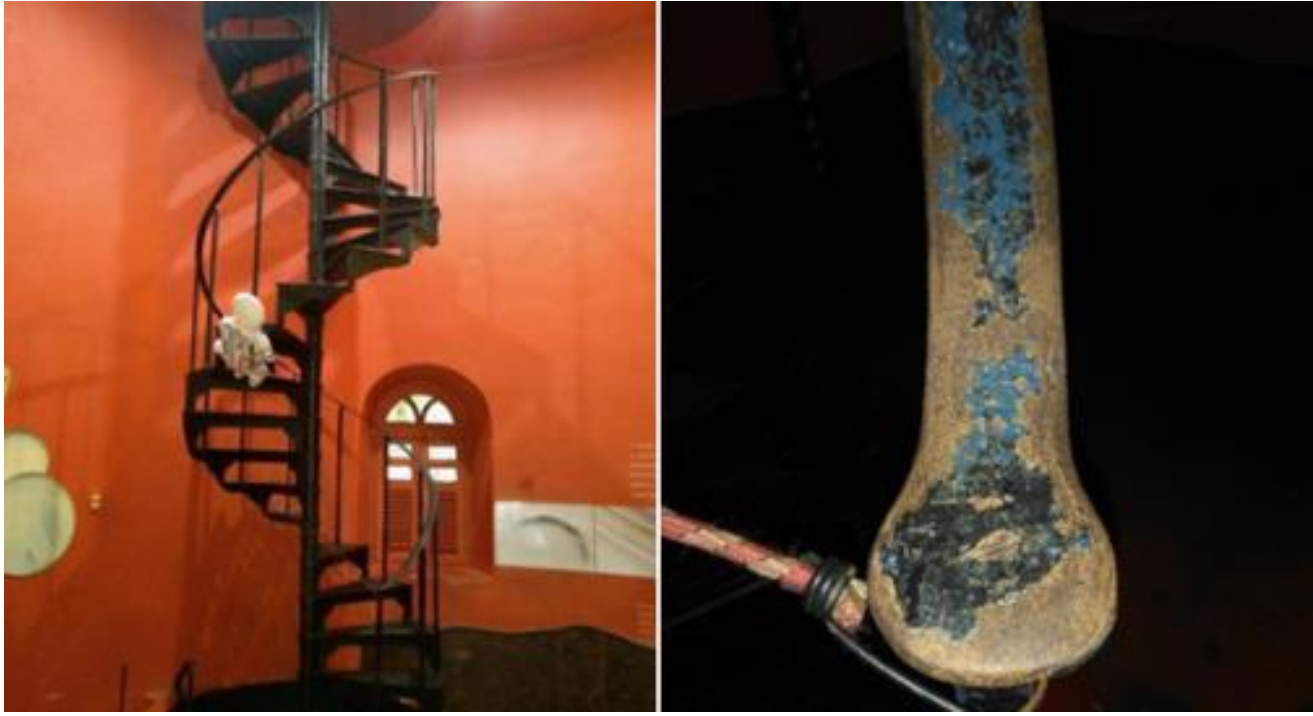

Figura 13 - Estado do material na escada.

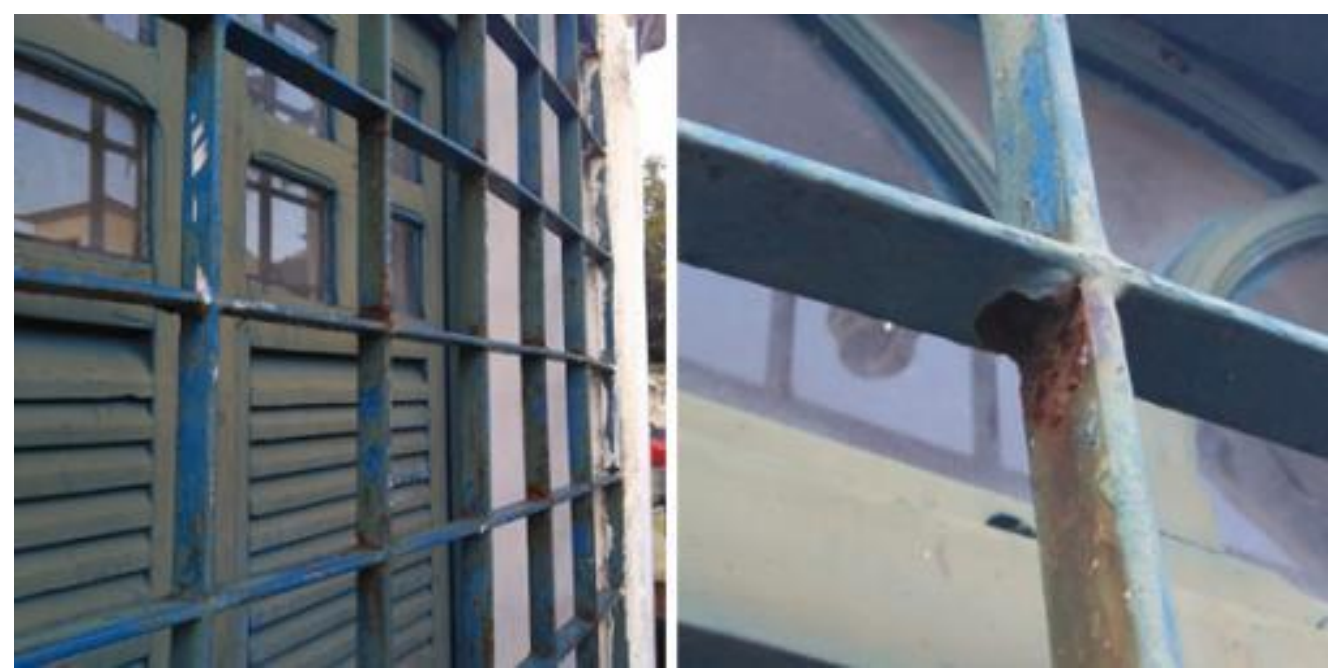

Figura 14 - Estado do material na grade da janela. 
Caracterização por Fluorescência de Raios X e Difração de Raios X

Na Figura 15 pode-se observar a localização exata das amostras OAS1 e OAS3 utilizadas nas análises de FRX e DRX.
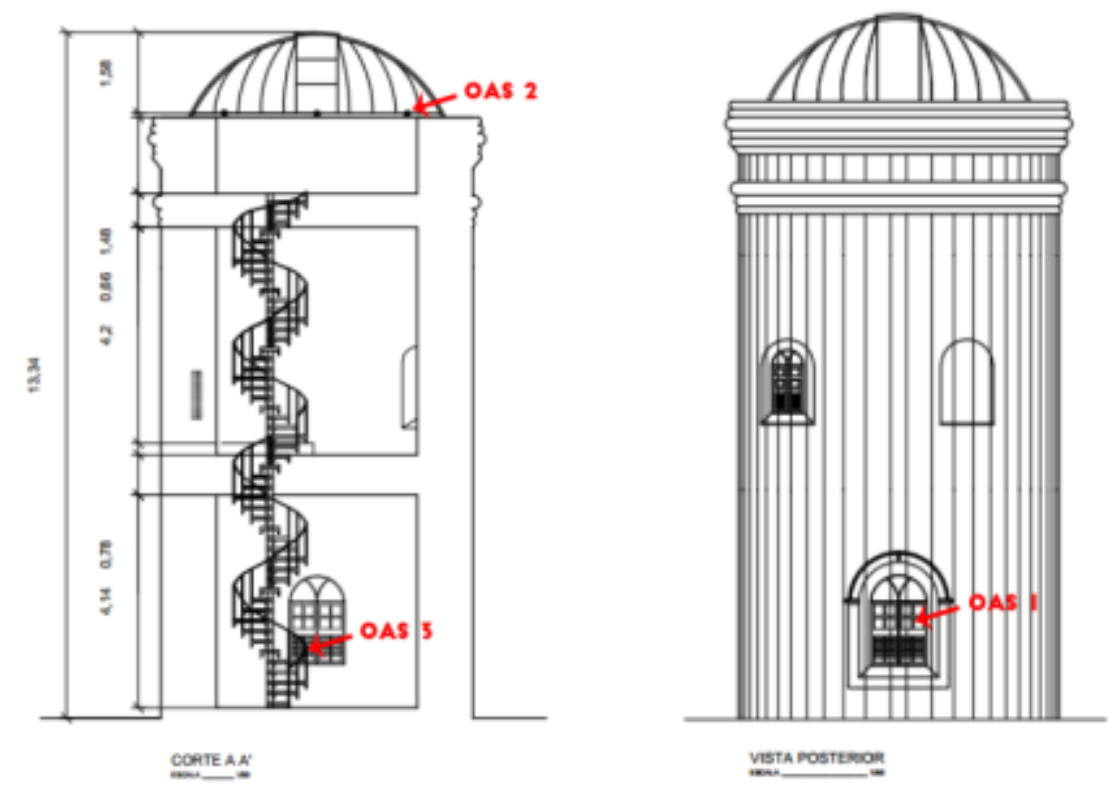

Figura 15 - Pontos de coleta das Amostras OAS1 e OAS3. Fonte: Acervo Pessoal.

Nas tabelas 1 e 2 são mostrados os resultados dos valores médios da análise elementar usando a FRX nas amostras OAS1 e OAS3, respectivamente, apesar de terem alguns elementos comuns a ambas, pode-se observar que a amostra OAS3 apresenta uma maior diversidade de elementos químicos, o que indica que se trata de estruturas bem diferentes.

Nas figuras 16 e 17 pode ser observado um comparativo dos elementos majoritários e minoritários, comuns a ambas. Podem ser observadas grandes diferenças na concentração dos elementos comuns, o que leva a acreditar que os elementos identificados na análise não se apresentam em decorrência do processo de degradação, mas do seu processo de molde e de construção.

Em se observando a amostra OAS3 apresenta o elemento Si que não é observado, nos valores médios, na amostra OAS1. Isso pode estar associado com a presença de tinta, a base deste elemento, utilizado para a proteção contra a ferrugem.

Tabela 1 - Análises FRX da Amostra OAS1

\begin{tabular}{|l|r|r|r|r|r|r|r|r|}
\hline \multicolumn{1}{|c|}{ Média das Análises da Amostra OAS1 } \\
\hline Elemento & \multicolumn{1}{|l|}{ Fe } & Mn & Ba & Ca & Sn & Ti & Cr \\
\hline ppm & 690783 & 4922 & 1927 & 944 & 379 & 301 & 281 \\
\hline STD & 1900 & 113 & 297 & 94 & 93 & 23 & 50 \\
\hline
\end{tabular}


Documentação e Mapeamento de Danos do Observatório Astronômico de Olinda e sua Correlação com a Caracterização Química e Mineralógica da sua Estrutura Metálica

Tabela 2 - Análises FRX da Amostra OAS3

\begin{tabular}{|c|c|c|c|c|c|c|c|c|c|c|c|c|c|}
\hline \multicolumn{14}{|c|}{ Média das Análises da Amostra OAS3 } \\
\hline Elemento & $\mathrm{Fe}$ & Si & $Z n$ & Ca & Ba & $\mathrm{Mn}$ & $\mathrm{Pb}$ & $\mathrm{Ti}$ & Sn & $\mathbf{v}$ & Sb & $\mathrm{Zr}$ & $\mathrm{Sr}$ \\
\hline ppm & 640817 & 24535 & 9352 & 4768 & 3209 & 3007 & 2087 & 1414 & 503 & 477 & 454 & 118 & 117 \\
\hline STD & 836 & 611 & 426 & 56 & 314 & 47 & 170 & 78 & 100 & 33 & 64 & 49 & 41 \\
\hline
\end{tabular}

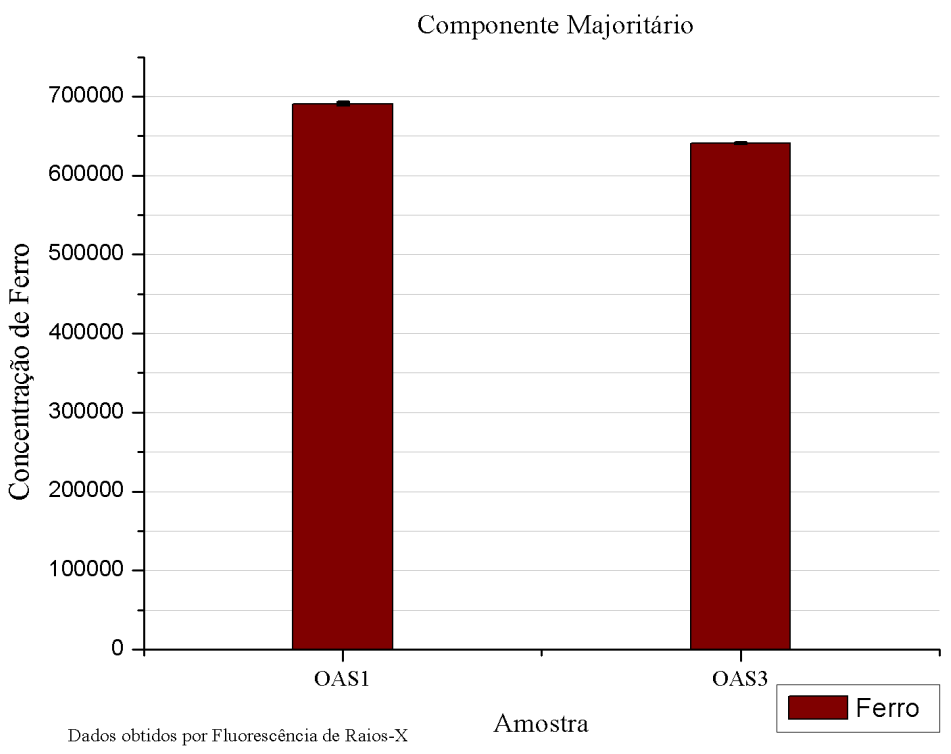

Figura 16 - Componente Majoritário nas amostras OAS1 e OAS3.

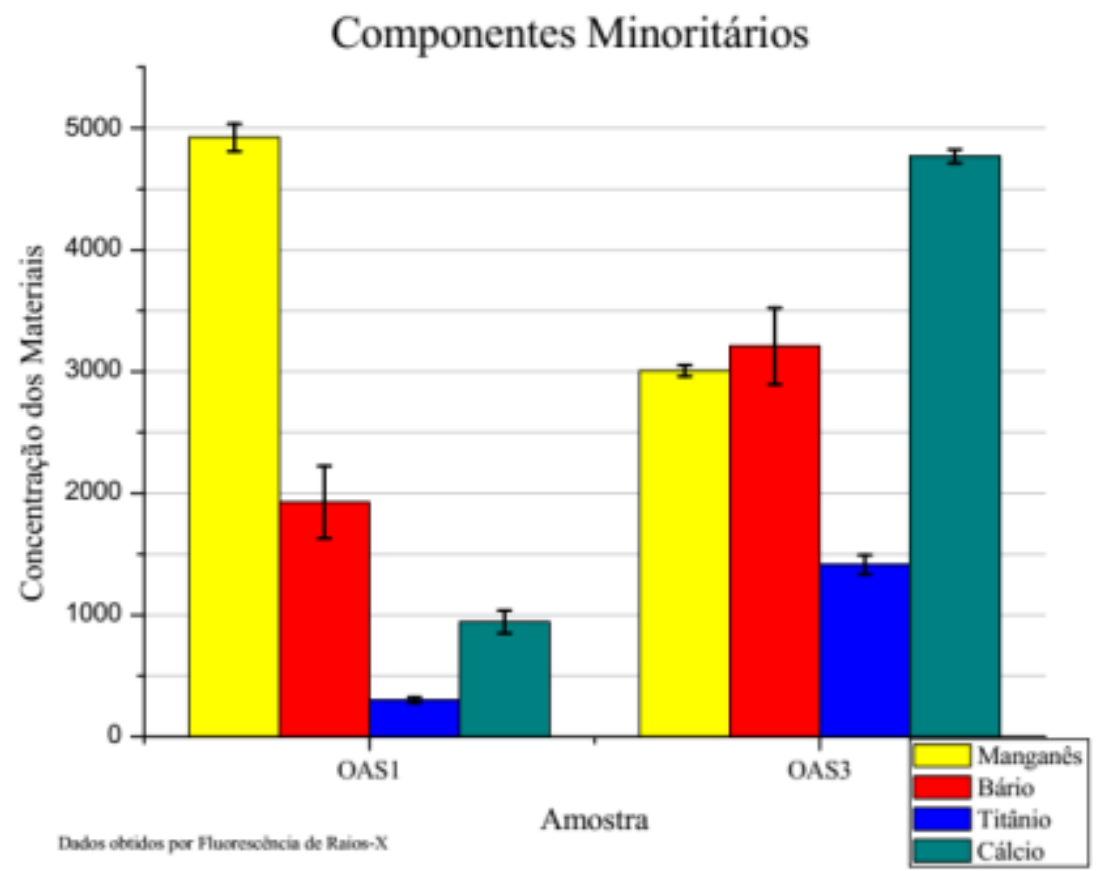

Figura 17 - Componentes Minoritários nas Amostras OAS1 e OAS3. 
A partir da análise de dados da difração, foi possível perceber uma maior quantidade de material amorfo, representado pela parte inferior do gráfico que não apresenta picos distinguíveis, resultantes da degradação dos metais, na estrutura da janela externa (Figura 18).

Na figura 19 pôde-se observar duas fases cristalinas na amostra OAS1 quartzo e magnetita. Por outro lado na figura 20, na amostra OAS3 (escada), é possível perceber a formação de grafite, resultado da decomposição da liga metálicae do próprio processo de fabricação da peça.

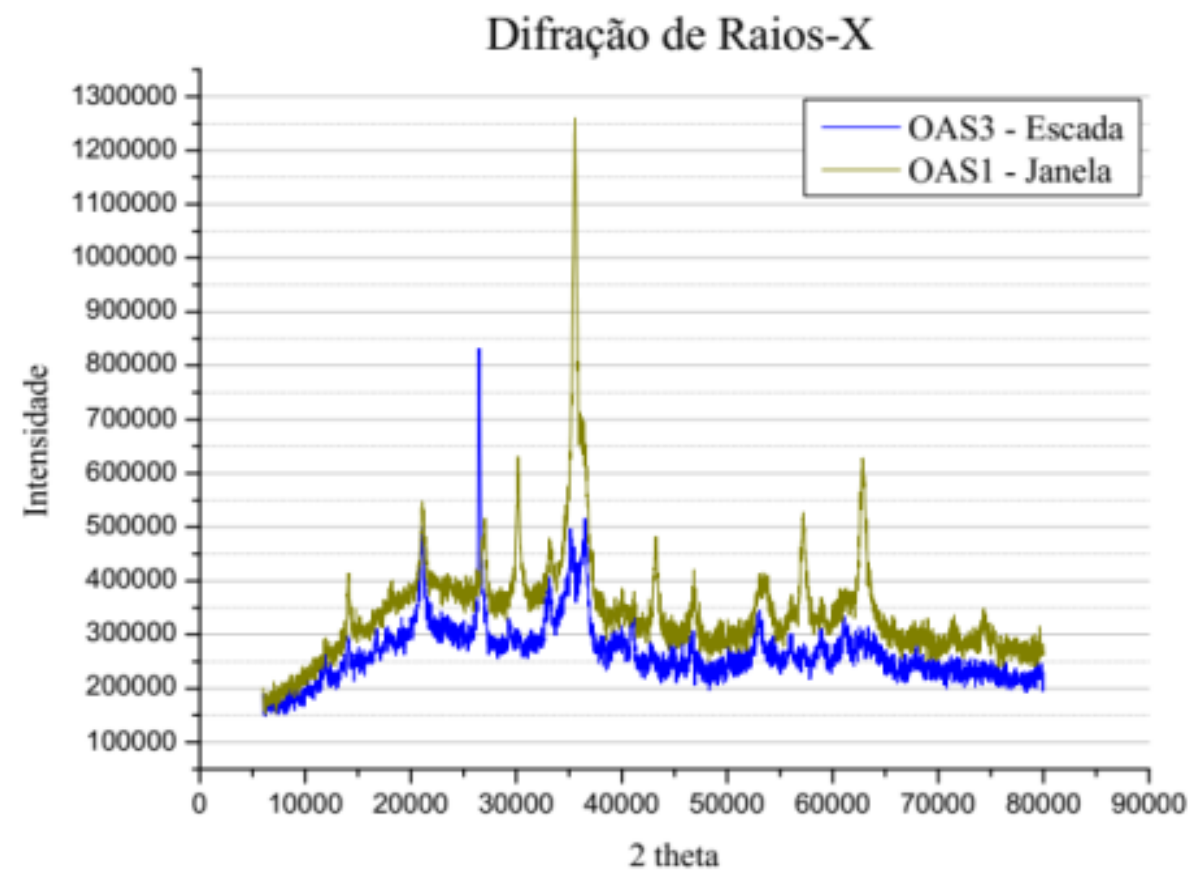

Figura 18 - Comparação entre as difrações das amostras OAS1 e OAS3.

\section{Diffraction Pattern Graphics}

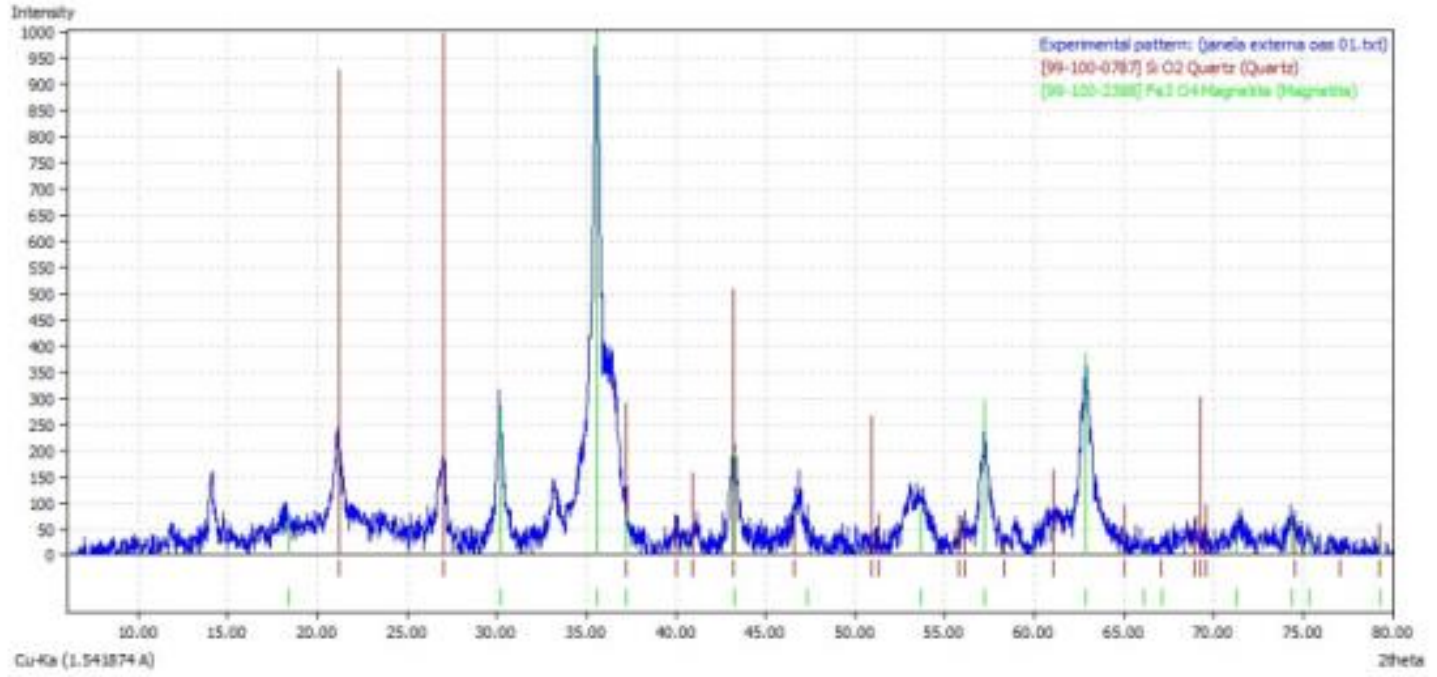

Figura 19 - Gráfico de difração da amostra OAS1 (Janela Externa). 
Documentação e Mapeamento de Danos do Observatório Astronômico de Olinda e sua Correlação com a Caracterização Química e Mineralógica da sua Estrutura Metálica

\section{Diffraction Pattern Graphics}

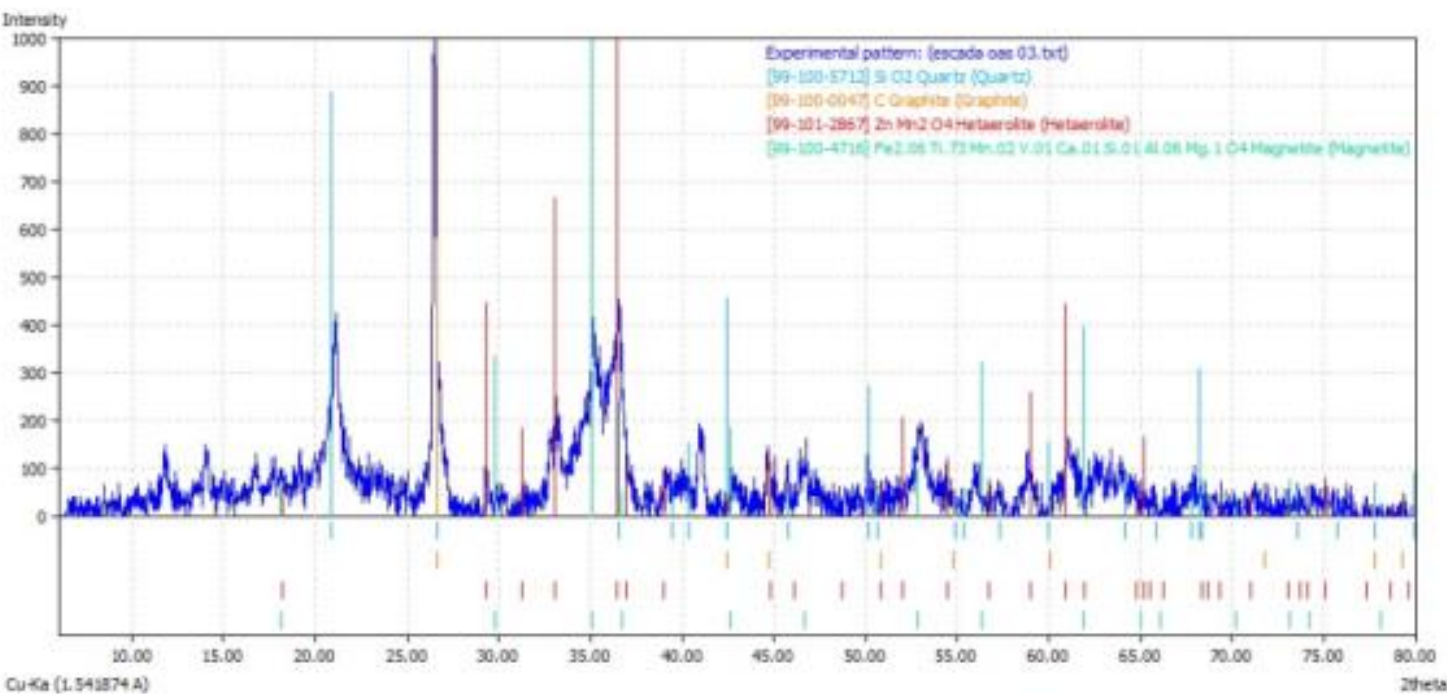

Figura 20 - Gráfico de difração da amostra OAS3 (Escada).

Além disso, percebe-se a presença de Quartzo $\left(\mathrm{SiO}_{2}\right)$ em ambas as amostras, porém em pouca quantidade, correlacionando este fato à não presença de Si nos resultados de FRX na amostra OAS1, pode-se afirmar que esta fase mineral tem presença pontual e não está distribuído de forma homogênea na amostra.

A presença de magnetita pode ser explicada pela produção do ferro, que "como alguns outros metais, não é encontrado na natureza em forma pura, sendo que nestas condições encontrase sempre combinado com outros elementos, formando óxidos, carbonatos, silicatos e sulfatos. Para a produção da formação do ferro são utilizados minérios, sobretudo os óxidos, tais como hematita $\left(\mathrm{Fe}_{2} \mathrm{O}_{3}\right)$ e a magnetita $\left(\mathrm{Fe}_{3} \mathrm{O}_{4}\right)$ ) (ZEQUINI, 2006). A presença de ambos os elementos não indica um processo de degradação do material, mas a sua presença no momento da produção.

Conforme Chiaverine (1986), a presença de silício na amostra OAS3, também pode ser explicado pela utilização de tintas envernizadas. Pelo tempo que a peça está na edificação, ela passou por vários processos de cobertura do ferro por tinta, o que pode, também, responder a presença deste componente.

Por meio das análises químicas não foi possível identificar indícios que apontassem diretamente para a patologia presente nos objetos de estudo. Entretanto, foi possível confirmar a hipótese de que se trata de compostos metálicos diferentes. A janela, uma liga de aço moderna, e a escada, uma estrutura de ferro fundido, mais antiga.

Tais características das peças foram o suficiente para levantar as patologias presentes, tendo em vista que o processo se difere em cada um dos materiais, a liga de aço e o ferro fundido. Apesar de não apresentar em sua composição química dados que fossem além da composição 
inicial das estruturas, as patologias em materiais metálicos, por muitas vezes, podem ser percebidas através de uma análise comparativa visual.

Assim, na janela externa pode-se identificar uma Corrosão Alveolar(Figura 21A), acelerada pela presença de sais na superfície. Por conta da proximidade geográfica com o mar, a janela se encontra constantemente exposta a gotículas de água do mar que são transportadas pelos ventos, processo comumente conhecido como maresia. Na escada, é facilmente identificável uma corrosão generalizada (Figura 21B), onde ocorre perda uniforme da espessura da estrutura.
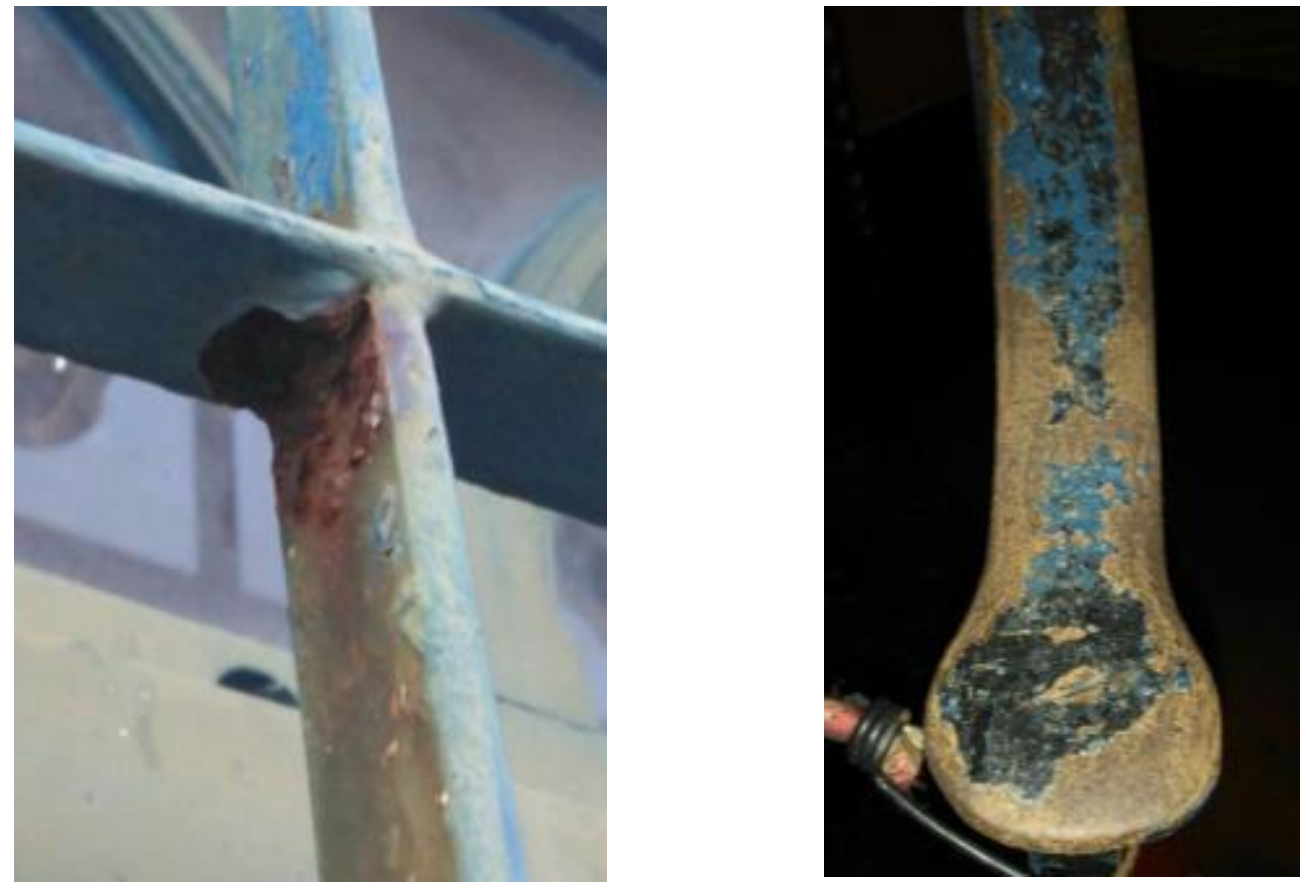

Figura 21 - A. Corrosão Alveolar na Janela Externa; B.Corrosão uniforme (ou generalizada) na Escada.

\section{Conclusão}

Na FRX, a amostra OAS 3 tinha quase o dobro do número de elementos quando comparada à OAS 1. Na DRX, os picos cristalinos da OAS 3 eram caracterizados, também, por um número de elementos superior à da outra amostra com a presença de menos material amorfo. As diferenças na composição das duas estruturas indicadas por está análise podem ser explicadas pela técnica usada para a sua produção, tendo em vista que a prática sofreu alterações através do tempo.

Estas mudanças podem ser vistas em Zequini, em 2006, onde são estudados os fornos para a fundição do ferro. Com a utilização de fornos a lenha, com presença de cal na construção desses fornos, que data entre os séculos XVI e XVIII e que englobam o período de construção do Observatório onde se inseriu a escada. Assim como as fundições da liga metálica da janela, que tem seu modo de produção exemplificado pelo planejamento de Araújo e Arenales de 2004, onde são realizados os processos de forma metódica por setores, com utilização de 
Documentação e Mapeamento de Danos do Observatório Astronômico de Olinda e sua Correlação com a Caracterização Química e Mineralógica da sua Estrutura Metálica

fornos e moldes, se tratando de um processo siderúrgico que possui um grau mínimo de contaminação por elementos exteriores, como pode ser visto no processo anterior da fundição do ferro.

Estes resultados, aliados à pesquisa histórica, confirmam então a hipótese de que os materiais provenientes de diferentes épocas apresentam composições diferentes. Sendo o primeiro (OAS 1) uma liga de aço moderna, inserida no edifício na restauração que aconteceu em 2004 e o segundo (OAS 3) ferro fundido de um período mais antigo, em que foi construído o observatório.

Quanto à relação entre a composição e o grau de degradação, não foi possível obter uma correlação através dos dados obtidos pelas técnicas de FRX e DRX. Entretanto, com base nas referências de patologias na literatura foi possível identificar os tipos de degradação das superfícies dos materiais, também levando em consideração que os fatores ambientais e climáticos possuem alto grau de influência na degradação das estruturas.

Para poder ter dados que correlacionem as patologias ao grau de degradação deste material, seria indicada a realização uma análise tanto no material danificado quanto em um material de mesma procedência (ferro fundido ou liga metálica) em boas condições.

\section{Referências}

ARAUJO, Anne Aguiar de. Gerenciamento de falhas por corrosão em dutos. Rio de Janeiro : Pontifícia Universidade Católica do Rio de Janeiro, Departamento de Engenharia Mecânica, 2012.

ARAUJO, Silvio Alexandra e ARENALES, Marcos Nereu. Planejamento e Programação da Produção numa Fundição Cativa Automatizada de Grande Porte. Investigação Operacional. 2004, 24, pp. 197-210.

BLEICHER, Lucas e SASAKI, José Marcos. 2000. Introdução à Difração de Raios X em cristais. Universidade do Ceará. Setembro, 2000

CALZA, C. 2010. Fluorescência de Raios X aplicada à análise de bens culturais. Boletim Eletrônico da ABRACOR. Junho, 2010.

CASTRO, Eduardo Mariano Cavalcante de. 1999. Patologia dos edifícios em estrutura metálica. Ouro Preto - MG : Universidade Federal de Ouro Preto, 1999.

CHIAVERINI, Vicente; Tecnologia Mecânica: Estrutura e propriedades das ligas metálicas, Vol I; Ed. McGraw-Hill Ltda, 1986.

COZZA, Eric. 1998. Uma nova era para o aço. Techné. 1998, n. 36, pp. 18-23.

GIARDINO, Claudio. 1998. I metalli nel mondo antico: introduzione all'archeometallurgia. s.l. : Laterza, 1998. 
LIAIS, Emmanuel, Eléments de la Comète découverte à Olinda le 26 Feévrier, 1860, d’après les Observations faites à l'Observatoire de Commission Scientifique, du 26 Février au 13Mars, Monthly Notices of the Royal Astronomical Society, vol 20, Issue 8, p 336.

LUCENA, Jorge Eduardo. 2009. Mapa de danos, recomendações básicas. Centro de Estudos Avançados de Conservação Integrada. 2009.

MATSUURA, Oscar Toshiaki. O Observatório no telhado. Recife: Companhia Editora de Pernambuco, 2010.

PALACHE, Charles. 1935. The minerals of Franklin and Stearling Hill Sussex County, New Jersey. United States, Government Printing Office. 1935.

PETRUCCI, Eládio G. R. 1978. Materiais de Construção. São Paulo : Editora Globo, 1978.

RIZZUTI, Bruno Ferreira; SILVA, Joilson Souza da. O antigo adapta-se ao moderno: verificação do valor da Unidade Astronômica a partir do trânsito de Vênus reproduzido com o software Stellarium. Rev. Bras. Ensino Fís., São Paulo, v. 38, n. 3, e3302, 2016.

SANTOS, Vanessa Sardinha Dos. "O que é Patologia?"; Brasil Escola. Disponível em <https://brasilescola.uol.com.br/o-que-e/biologia/o-que-patologia.htm>. Acesso em 18 de marco de 2018.

SARTORTI, Artur Lenz. 2008. Identificação de patologias em pontes de vias urbanas ruraisno município de Campinas-SP. Campinas : Universidade Estadual de Campinas, 2008.

TIRELLO, Regina Andrade e CORRÊA, Rodolpho. 2010. Sistema normativo para mapa de danos de edifícios históricos. Universidade Estadual de Campinas. 2010.

ZEQUINE, Anicleide. 2006. Arqueologia de uma fábrica de ferro: Morro de Araçoiaba séculos XVI-XVIII. Dezembro, 2006. 